Invited Commentary for International Psychogeriatrics: Time to invest in better dementia care

\title{
Time to invest in prevention and better care of behaviours and psychological symptoms associated with dementia
}

$1,7 \underline{70} 34$ words, $5 \underline{7} 5$ references, 2 tables

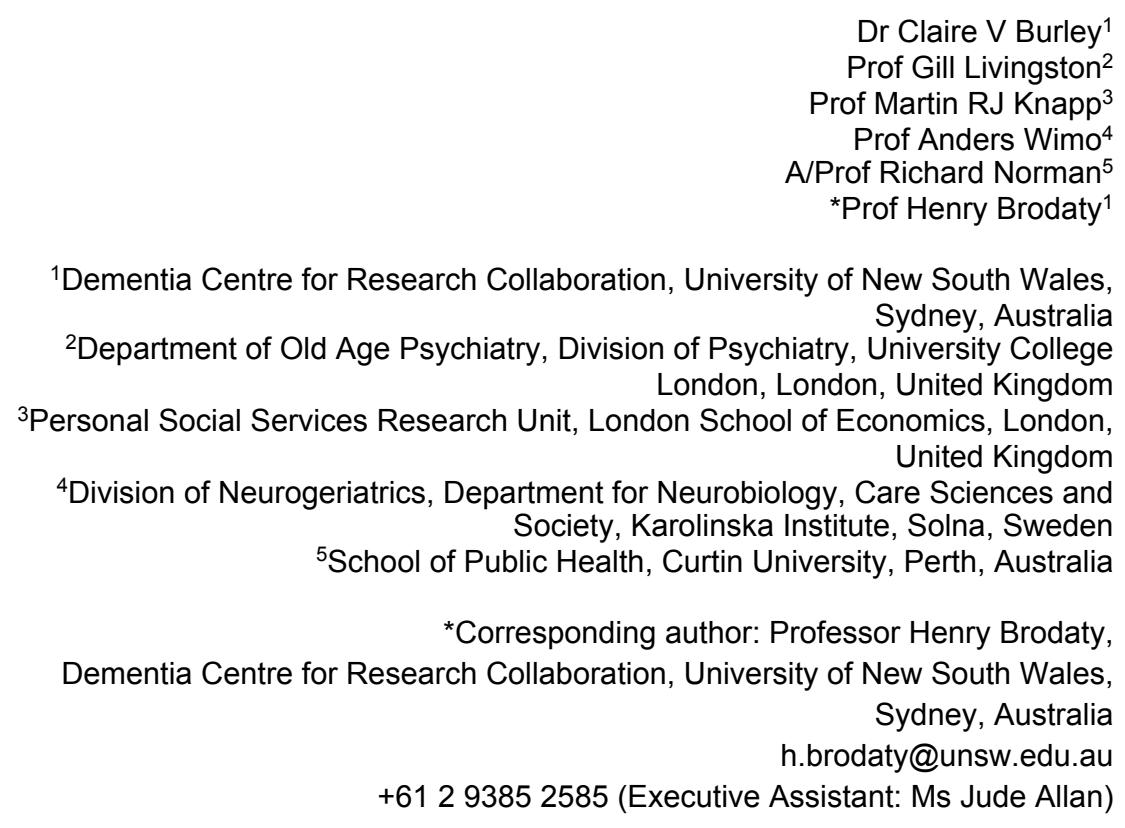

\section{Keywords}

Behaviours and psychological symptoms associated with dementia (BPSD), care, cost-effectiveness, cognitive therapy, dementia, psychosocial, physical activity, nonpharmacological, therapeutic activities

\section{Conflicts of interest}

The authors have no conflicts of interest to declare. 
Invited Commentary for International Psychogeriatrics: Time to invest in better dementia care

While dementia is defined as cognitive decline leading to functional impairment, behaviours and psychological symptoms (BPSD; also referred to as 'neuropsychiatric symptoms', 'changed behaviours', 'behavioural and psychological symptoms of dementia', 'responsive behaviours'; see Cunningham and colleagues) ${ }^{1}$ which become almost universal as dementia becomes more severe, often cause more distress to people with dementia and their families and account for much of the cost (see Lancet commission). ${ }^{2}$ Symptoms comprise aggression, agitation, anxiety, apathy, depression, disinhibited behaviours, nocturnal disruption, psychotic symptoms, vocally disruptive behaviours, and wandering.

These behaviours and symptoms impose a large financial burden, as they cause family and carer partner distress, which also predicts early care home admission, ${ }^{3,4}$ higher use of emergency department $t^{5}$ and other health facilities; ${ }^{6}$-as well as requiring direct care ${ }^{7,8}$ in care facilities and the community. ${ }^{8}$

Behaviours and psychological symptoms are a key driver of the rapidly escalating social and economic costs of dementia globally. This paper poses the question: Do the economic benefits of non-pharmacological approaches in preventing and managing BPSD outweigh the costs?

The rising prevalence of dementia (currently 50 million people worldwide, estimated to reach 82 million by 2030 and 152 million by 2050; www.alz.co.uk/research/statistics) leads to rapidly increasing costs (currently over US $\$ 1$ trillion, estimated to reach $\$ 2$ trillion by $2030,{ }^{3}$ to which BPSD have been shown to contribute over $25 \%$ of total indirect and $35 \%$ of total direct annual costs (i.e., $\$ 2,665$ and $\$ 1,450$ respectively in an individual patient) of care in an Israeli community setting. ${ }^{4}$ This may not be surprising as BPSD are ubiquitous, affecting < up to $90 \%$ of people during the course of dementia and strongly correlate with functional and cognitive impairment. also cause family and carer partner distress, which predicts loss of independence, ${ }^{7}$ early care home admission, ${ }^{8,9,10}$ higher use of emergency department ${ }^{11}$ and other health facilities: ${ }^{12}$ as well as requiring direct care ${ }^{4,13}$ in care facilities and the community. ${ }^{14}$

loss of independence, ${ }^{13}$ and care home admission. ${ }^{4,14}$ 
Invited Commentary for International Psychogeriatrics: Time to invest in better dementia care

The contribution of agitation to dementia costs has been reported to increase informal care costs in a homecare setting ${ }^{15}$ by $17 \%$ and increase overall costs ${ }^{16,17}$ by $22 \%$. In care homes agitation accounts for $44 \%$ of excess costs on top of the costs of the home itself; ${ }^{18-20}$ indicating that calculated costs depend on the setting and increase in a dose-dependent manner with symptom severity (i.e., higher scores on the neuropsychiatric inventory (NPI); see also Herrmann ${ }^{21}$ and Gustavsson ${ }^{14}$ and colleagues).

Evidence is accumulating that nonpharmacological (also known as psychosocial) interventions and person-centred care can reduce agitation and other behaviours. ${ }^{2,22}$ Yet there are difficulties in sustaining implementation and change in practice beyond the period of the intervention. ${ }^{18}$ This is perhaps because implementing change takes practice and time, practice to bed in and additional support as these approaches are not built into the care environment. There may also be concerns about cost and staff time, driven by insufficient awareness of studies that have focused specifically on cost analysis ofing BPSD and demonstrated the potential savings that can be made by investing in treatments that are symptom targeted and individualised (i.e., personcentred). Without a strong case for intervention- and cost-effectiveness, resistance to implementing change remains high, from managers and care workers at the local level, to policy makers, political leaders and societies at the macro-level.

We reasoned that demonstration of cost-effectiveness could further incentivise governments, funders and service providers to invest in practice change and the implementation of effective person-centred approaches. We scoped-reviewed the literature to calculate monetary costs of individual BPSD and their management, in order to determine whether there was evidence of financial benefits to convince policy makers and service providers to change practices to reduce BPSD.

\section{Nonpharmacological interventions for BPSD}

Nonpharmacological interventions, including well powered randomised controlled trials (RCTs), shown to be effective in reducing BPSD include: person-centred care,${ }^{23-26}$ reminiscence-based approaches, ${ }^{27,28}$ aerobic and resistance exercise, ${ }^{29}$ music, ${ }^{30,31}$ use of a robotic or soft seal, ${ }^{32,33}$ humour therapy, ${ }^{34,35}$ and educational 
Invited Commentary for International Psychogeriatrics: Time to invest in better dementia care

training. ${ }^{36,37}$ Specifically, person-centred care led to improvements in agitation

2 revealed with the Cohen-Mansfield Agitation Inventory (CMAI) or Neuropsychiatric

3 Inventory (NPI), reminiscence therapy improved apathy and depression measured

4 using the Apathy Evaluation Scale (AES) and the Cornell Scale for Depression in

5 Dementia (CSDD), and physical activity improved depression (determined with

6 CSDD) and other BPSD (see Livingston and colleagues ${ }^{2}$ ).

Barriers to adoption of these practices include the heterogeneity of interventions, the lack of rigour in their evaluation and concerns surrounding cost, resources and staff time. Cost-effectiveness analyses can illustrate how an outcome may (or may not) be desirable, despite what may otherwise be perceived as involving high costs. Simplistically this involves identifying the associated benefits of the intervention as well as the associated costs and subtracting the costs from the benefits. This approach is crucial (rather than focusing only on cost savings) given that to care effectively for people living with dementia and BPSD, competent and confident trained healthcare workers and adequate staff numbers are essential.

\section{Costing BPSD}

Cross-sectional, prospective and longitudinal studies have investigated costs of BPSD (usually agitation) and have used either group comparison approaches (i.e. based on dementia severity) or linear regression approaches to determine costs per unit increase on an individual symptom measure (see Table 1 for summary). Caution should be taken when interpreting findings from cross-sectional studies due to unclear causal mechanisms. We have focused primarily on prospective and longitudinal studies. Costs of BPSD differ between community, clinic, hospital and residential settings in line with differences in dependency levels and costs of care. ${ }^{38}$ Costs are generally calculated using used a general linear mixed model including relevant covariates to estimate main predictors of costs.

In a 1-year prospective study of resource utilisation, a 1-point increase in agitation determined by the NPI resulted in an increase in costs of US $\$ 30$ per month, ${ }^{21}$ where total cost of care was calculated to be US $\$ 1,298$ per month. Other studies have reported between $1.6-17 \%$ increase in costs per 1 -point increase on the total NPI in 
Invited Commentary for International Psychogeriatrics: Time to invest in better dementia care

a community setting. ${ }^{15,39-41}$ Some studies have considered variability and used 2 standard deviations to compute costs where an increase of one standard deviation in 3 NPI severity translated into a $6 \%$ and $8.8 \%$ increase in costs. ${ }^{14,38}$ While studies tend 4 to focus on agitation, one study found apathy and hallucinations were the biggest 5 contributors and significantly increased costs $\left(p=0.0016\right.$ and $p<0.0001$ respectively) ${ }^{38}$

Several intervention studies have calculated cost-effectiveness analyses in this area. 8 In these, they calculated an incremental cost-effectiveness ratio (ICER). The ICER is 9 calculated as the difference in total cost between two intervention groups, divided by the difference in outcome measures (e.g., agitation measured using CMAI or NPI) between the two intervention groups (see Table 2 for summary). ${ }^{25,32,42,43}$ 'Willingness to pay' for additional units of outcome has also been included in calculations to plot cost-effectiveness acceptability curves (CEACs) ${ }^{44}$ and determine if, from a societal perspective, an intervention is effective by leading to a clinically meaningful improvement in BPSD. For example, D'Amico and colleagues' study calculated a clinically meaningful reduction in NPI (i.e., three points) to cost $£ 1,263$ and calculated a willingness to pay $£ 500$ per increment improvement (i.e., per 1-point decrease in NPI score) would mean the probability of exercise being cost-effective would be higher than 80 percent. ${ }^{45,46}$

In a systematic review of worldwide studies costing individual $\mathrm{BPSD}^{18}$ the cost of 30 interventions that had a significant impact on agitation was calculated, 11 of which used the CMAI. In total, health and social care costs in people without clinically significant symptoms in NPI agitation over three months were calculated to be around $£ 7,000$ compared to $£ 15,000$ for those with the most severe levels of agitation. The incremental cost per unit reduction in CMAI score following therapeutic activities was reported to be $£ 162$ for Montessori-based activities ${ }^{47}$ and $£ 3,480$ for a highly structured programme of sensorimotor activities. ${ }^{48}$ The cost per unit were calculated for music therapy ${ }^{49}$ at $£ 4$ and sensory interventions using acupressure ${ }^{50,47}$ at $£ 24$ and $£ 143$ respectively. Training paid caregivers in person-centred care or communication skills $^{25,51,52}$ was costed at $£ 6, £ 42$ and $£ 62$ respectively per unit reduction in CMAI.

The main health outcome measure used by the National Institute for Health and Clinical Excellence (NICE) and many other national reimbursement authorities is the 
Invited Commentary for International Psychogeriatrics: Time to invest in better dementia care

quality-adjusted life-year (QALY). A QALY is a unit that combines both quantity (length) of life and health-related quality of life into a single measure of health gain (NICE guidelines 2008,53 page 17). Cost-effectiveness is also often calculated considering improvements in quality of life. An RCT of an intervention to consider and address needs of residents with agitation and improve communication did not improve agitation but was cost-effective in improving quality of life..$^{19}$ Livingston and colleagues $^{18}$ measured cost-effectiveness as the mean QALYs gained per patient accrued to the intervention multiplied by the decision-makers' maximum willingness to pay for a QALY, minus the mean incremental cost per patient for the intervention (termed net monetary benefits (NMBs)). This model converts the gain or loss in outcomes associated with the intervention into monetary units and subtracts the associated cost of the intervention to determine cost-effectiveness (NMB $>0$ represents good value for money). A willingness to pay $£ 20,000$ for a QALY (see UK NICE guidelines, ${ }^{53}$ page 18 ) equated to an 82 percent probability of being costeffective. ${ }^{18}$ QALYs are frequently used to access health outcomes and are used in calculating ICER, though have several limitations in the field of dementia research and the clinical relevance of quality of life measures (i.e., QALYs) has been questioned.

Methodological inconsistencies and the techniques used to value informal care ${ }^{39}$ make it difficult to compare findings across studies. Despite the variability in calculations and reporting approaches of symptom costs, all studies demonstrate that BPSD contribute significantly to the overall costs of dementia care. There is a general focus on agitation; costing of other symptoms is lacking apart from one study on apathy ${ }^{21}$ even though other symptoms such as apathy, anxiety and depression can cause significant distress, ${ }^{10}$ which would likely impact on costs. Several-Other cost-effectiveness-studies using person-centred and staff training approaches ${ }^{23,26}$ 55 have reported -cost-effectiveness though have not costed symptoms separately $\$ 6,54,56$ alsoA UK study- found significant improvements in quality of life and BPSD in response topeople living with dementia following the intervention. person-centred approaches 236,54 However, improvements in BPSD were not observed in people with young-onset dementia in a Dutch study; possibly due to overlap between the intervention and specialised methods of care already in use for treatment as usual. ${ }^{55}$ hough these have not costed symptoms separately.

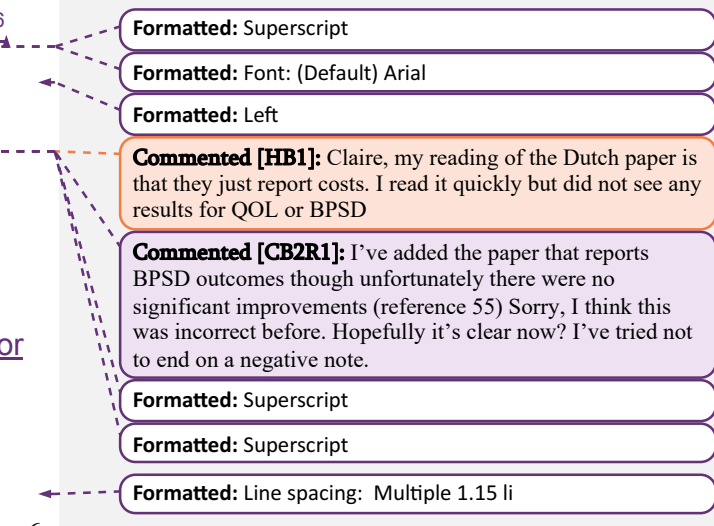

Formatted: Font: (Default) Aria

Commented [HB1]: Claire, my reading of the Dutch paper is costs. I read it quickly but did not see any Commented [CB2R1]: I've added the paper that reports Coutcomes though unfortunately there were no
Formatted: Line spacing: 1.5 lines 
Invited Commentary for International Psychogeriatrics: Time to invest in better dementia care

\section{Time for action}

Barriers to achieving better value for money in dementia care include reluctance to implement evidence, poor coordination of health and social care provision and financing $=\frac{557}{1-}$ Evidence is presented of monetary costs of BPSD and of benefits of 6 interventions. The few studies that have built cost-effectiveness analyses into their 7 design indicate the economic feasibility of adopting non-pharmacological approaches 8 such as person-centred care into everyday practice. This will require change in 9 attitudes and care practice. 


\section{References}

1. Cunningham $\mathrm{C}$, Macfarlane $\mathrm{S}$, Brodaty $\mathrm{H}$. Language paradigms when behaviour changes with dementia:\# BanBPSD. International Journal of Geriatric Psychiatry 2019; 34(8):1109-1113.

2. Livingston G, Sommerlad A, Orgeta V, Costafreda SG, Huntley J, Ames D, et al. Dementia prevention, intervention, and care. The Lancet Commissions 2017;390(10113):2673-734.

3. Wimo A, Guerchet M, Ali G-C, Wu Y-T, Prina AM, Winblad B, et al. The worldwide costs of dementia 2015 and comparisons with 2010. Alzheimer's \& Dementia 2017;13(1):1-7.

4. Beeri MS, Werner P, Davidson M, Noy S. The cost of behavioral and psychological symptoms of dementia (BPSD) in community dwelling Alzheimer's disease patients. International Journal of Geriatric Psychiatry 2002;17(5):403-8.

5. Brodaty H, Draper B, Saab D, Low LF, Richards V, Paton H, et al. Psychosis, depression and behavioural disturbances in Sydney nursing home residents: prevalence and predictors. International Journal of Geriatric Psychiatry 2001;16(5):504-12.

6. Cerejeira J, Lagarto L, Mukaetova-Ladinska E. Behavioral and psychological symptoms of dementia. Frontiers in Neurology 2012;3:73.

7. Åkerborg Ö, Lang A, Wimo A, Sköldunger A, Fratiglioni L, Gaudig M, et al. Cost of dementia and its correlation with dependence. Journal of Aging and Health 2016;28(8):1448-64.

8. Maust DT, Kales HC, McCammon RJ, Blow FC, Leggett A, Langa KM. Distress associated with dementia-related psychosis and agitation in relation to healthcare utilization and costs. The American Journal of Geriatric Psychiatry 2017;25(10):1074-82.

9. Belger M, Haro JM, Reed C, Happich M, Argimon JM, Bruno G, et al. Determinants of time to institutionalisation and related healthcare and societal costs in a community-based cohort of patients with Alzheimer's disease dementia. The European Journal of Health Economics 2018;20(3):343-355.

10. Feast A, Moniz-Cook E, Stoner C, Charlesworth G, Orrell MJIp. A systematic review of the relationship between behavioral and psychological symptoms (BPSD) and caregiver well-being. International Psychogeriatrics 2016;28(11):1761-74

11. Guterman EL, Allen IE, Josephson SA, Merrilees JJ, Dulaney S, Chiong W, et al. Association Between Caregiver Depression and Emergency Department Use Among Patients With Dementia. JAMA Neurology 2019; doi: 10.1001/jamaneurol.2019.1820.

12. Aigbogun MS, Stellhorn R, Hartry A, Baker RA, Fillit H. Treatment patterns and burden of behavioral disturbances in patients with dementia in the United States: a claims database analysis. BMC Neurology 2019;19(1):33.

13. Brown L, Hansnata E, La HA. Economic Cost of Dementia in Australia. Alzheimer's Australia, Canberra. 2017.

14. Gustavsson A, Brinck P, Bergvall N, Kolasa K, Wimo A, Winblad B, et al Predictors of costs of care in Alzheimer's disease: a multinational sample of 1222 patients. Alzheimer's \& Dementia 2011;7(3):318-27.

15. Costa N, Wübker A, De Mauléon A, Zwakhalen SM, Challis D, Leino-Kilpi H, et al. Costs of care of agitation associated with dementia in 8 European countries: results from the RightTimePlaceCare study. JAMDA 2018;19(1):95.e1-e10. 
16. Morris S, Patel N, Baio G, Kelly L, Lewis-Holmes E, Omar RZ, et al. Monetary costs of agitation in older adults with Alzheimer's disease in the UK: prospective cohort study. BMJ Open 2015;5(3):e007382.

17. Sköldunger A, Wimo A, Sjögren K, Björk S, Backman A, Sandman PO, et al. Resource use and its association to cognitive impairment, ADL functions, and behavior in residents of Swedish nursing homes: Results from the U-Age program (SWENIS study). International Journal of Geriatric Psychiatry 2019;34:130-6.

18. Livingston G, Kelly L, Lewis-Holmes E, Baio G, Morris S, Patel N, et al. A systematic review of the clinical effectiveness and cost-effectiveness of sensory, psychological and behavioural interventions for managing agitation in older adults with dementia. Health Technology Assessment (Winchester, England) 2014;18(39):1-226, v-vi.

19. Livingston G, Barber J, Marston L, Stringer A, Panca M, Hunter R, et al. Clinical and cost-effectiveness of the managing agitation and raising quality of life (MARQUE) intervention for agitation in people with dementia in care homes: a single-blind, cluster-randomised controlled trial. The Lancet Psychiatry 2019;6(4):293-304.

20. Panca M, Livingston G, Barber J, Cooper C, La Frenais F, Marston L, et al. Healthcare resource utilisation and costs of agitation in people with dementia living in care homes in England-The Managing Agitation and Raising QUality of LifE in Dementia (MARQUE) study. Plos One 2019;14(2):e0211953.

21. Herrmann N, Lanctôt KL, Sambrook R, Lesnikova N, Hébert R, McCracken P, et al. The contribution of neuropsychiatric symptoms to the cost of dementia care. International Journal of Geriatric Psychiatry 2006;21(10):972-6.

22. Burns K, Jayasinha R, Tsang R, Brodaty H. Behaviour Management: A Guide to Good Practice, Managing Behavioural and Psychological Symptoms of Dementia 2012. Dementia Centre for Research Collaboration, University of New South Wales, Sydney.

23. Fossey J, Ballard C, Juszczak E, James I, Alder N, Jacoby R, et al. Effect of enhanced psychosocial care on antipsychotic use in nursing home residents with severe dementia: cluster randomised trial. BMJ 2006;332(7544):756-61.

24. Chenoweth L, Forbes I, Fleming R, King MT, Stein-Parbury J, Luscombe G, et al. PerCEN: a cluster randomized controlled trial of person-centered residential care and environment for people with dementia. International Psychogeriatrics 2014;26(7):1147-60.

25. Chenoweth L, King MT, Jeon $Y-H$, Brodaty H, Stein-Parbury J, Norman R, et al. Caring for Aged Dementia Care Resident Study (CADRES) of personcentred care, dementia-care mapping, and usual care in dementia: a clusterrandomised trial. The Lancet Neurology 2009;8(4):317-25.

26. Tay FHE, Thompson CL, Nieh CM, Nieh CC, Koh HM, Tan JJC, et al. Personcentered care for older people with dementia in the acute hospital. Alzheimer's \& Dementia: Translational Research \& Clinical Interventions 2018;4:19-27.

27. Duru Aşiret G, Kapucu SJJogp, neurology. The effect of reminiscence therapy on cognition, depression, and activities of daily living for patients with Alzheimer disease. Journal of Geriatric Psychiatry and Neurology 2016;29(1):31-7.

28. Davison TE, Nayer K, Coxon S, de Bono A, Eppingstall B, Jeon Y-H, et al. A personalized multimedia device to treat agitated behavior and improve mood in people with dementia: a pilot study. Geriatric Nursing 2016;37(1):25-9. 
29. Cancela JM, Ayán C, Varela S, Seijo MJJos, sport mi. Effects of a long-term aerobic exercise intervention on institutionalized patients with dementia. Journal of Science and Medicine in Sport 2016;19(4):293-8.

30. Clément S, Tonini A, Khatir F, Schiaratura L, Samson S. Short and longer term effects of musical intervention in severe Alzheimer's disease. Music Perception: An Interdisciplinary Journal 2012;29(5):533-41.

31. Raglio A, Bellandi D, Baiardi P, Gianotti M, Ubezio MC, Zanacchi E, et al. Effect of active music therapy and individualized listening to music on dementia: a multicenter randomized controlled trial. Journal of the American Geriatrics Society 2015;63(8):1534-9.

32. Mervin MC, Moyle W, Jones C, Murfield J, Draper B, Beattie E, et al. The CostEffectiveness of Using PARO, a Therapeutic Robotic Seal, to Reduce Agitation and Medication Use in Dementia: Findings from a Cluster-Randomized Controlled Trial. JAMDA 2018;19(7):619-22. e1.

33. Jøranson N, Pedersen I, Rokstad AMM, Ihlebaek C. Effects on symptoms of agitation and depression in persons with dementia participating in robotassisted activity: a cluster-randomized controlled trial. Journal of the American Medical Directors Association 2015;16(10):867-73.

34. Low L-F, Brodaty H, Goodenough B, Spitzer P, Bell J-P, Fleming R, et al. The Sydney Multisite Intervention of LaughterBosses and ElderClowns (SMILE) study: cluster randomised trial of humour therapy in nursing homes. BMJ Open 2013;3(1):e002072.

35. Brodaty H, Low L-F, Liu Z, Fletcher J, Roast J, Goodenough B, et al. Successful ingredients in the SMILE study: resident, staff, and management factors influence the effects of humor therapy in residential aged care. The American Journal of Geriatric Psychiatry 2014;22(12):1427-37.

36. Ballard C, Orrell M, Sun Y, Moniz-Cook E, Stafford J, Whitaker R, et al. Impact of antipsychotic review and non-pharmacological intervention on health-related quality of life in people with dementia living in care homes: WHELD—a factorial cluster randomised controlled trial. International Journal of Geriatric Psychiatry 2017;32(10):1094-103.

37. Lichtwarck B, Selbaek G, Kirkevold Ø, Rokstad AMM, Benth JŠ, Lindstrøm JC, et al. Targeted interdisciplinary model for evaluation and treatment of neuropsychiatric symptoms: a cluster randomized controlled trial. The American Journal of Geriatric Psychiatry 2018;26(1):25-38.

38. Wübker A, Zwakhalen SM, Challis D, Suhonen R, Karlsson S, Zabalegui A, et al. Costs of care for people with dementia just before and after nursing home placement: primary data from eight European countries. The European Journal of Health Economics 2015;16(7):689-707.

39. Jönsson L, Jönhagen ME, Kilander L, Soininen H, Hallikainen M, Waldemar G, et al. Determinants of costs of care for patients with Alzheimer's disease. International Journal of Geriatric Psychiatry 2006;21(5):449-59.

40. Lacey LA, Niecko T, Leibman C, Liu E, Grundman MJTjon, health, aging. Association between illness progression measures and total cost in Alzheimer's disease. The Journal of Nutrition, Health \& Aging 2013;17(9):745-50.

41. Rattinger GB, Schwartz S, Mullins CD, Corcoran C, Zuckerman IH, Sanders C, et al. Dementia severity and the longitudinal costs of informal care in the Cache County population. Alzheimer's \& Dementia 2015;11(8):946-54.

42. Mintzer JE, Colenda C, Waid LR, Lewis L, Meeks A, Stuckey M, et al. Effectiveness of a continuum of care using brief and partial hospitalization for agitated dementia patients. Psychiatric Services 1997;48(11):1435-9. 
Invited Commentary for International Psychogeriatrics: Time to invest in better dementia care

43. Norman $\mathrm{R}$, Haas $\mathrm{M}$, Chenoweth $\mathrm{L}$, Jeon $\mathrm{Y}-\mathrm{H}$, King M, Brodaty $\mathrm{H}$, et al. Dementia Care Mapping and Patient-Centred Care in Australian residential homes: An economic evaluation of the CARE Study, CHERE Working Paper 2008/4. 2008

44. Fenwick E, O'Brien BJ, Briggs A. Cost-effectiveness acceptability curves-facts, fallacies and frequently asked questions. Health Economics 2004;13(5):405-15.

45. D'Amico F, Rehill A, Knapp M, Lowery D, Cerga-Pashoja A, Griffin M, et al. Cost-effectiveness of exercise as a therapy for behavioural and psychological symptoms of dementia within the EVIDEM-E randomised controlled trial. International Journal of Geriatric Psychiatry 2016;31(6):656-65.

46. Vroomen JM, Bosmans JE, Eekhout I, Joling KJ, van Mierlo LD, Meiland FJ, et al. The cost-effectiveness of two forms of case management compared to a control group for persons with dementia and their informal caregivers from a societal perspective. Plos One 2016;11(9):e0160908.

47. Lin LC, Yang MH, Kao CC, Wu SC, Tang SH, Lin JG. Using acupressure and Montessori-based activities to decrease agitation for residents with dementia: a cross-over trial. Journal of the American Geriatrics Society 2009;57(6):1022-9.

48. Buettner L, Ferrario J. Therapeutic recreation-nursing team: A therapeutic intervention for nursing home residents with dementia. Annual in Therapeutic Recreation 1998;7:21-8.

49. Lin Y, Chu H, Yang CY, Chen CH, Chen SG, Chang HJ, et al. Effectiveness of group music intervention against agitated behavior in elderly persons with dementia. International Journal of Geriatric Psychiatry. 2011;26(7):670-8.

50. Yang MH, Wu SC, Lin JG, Lin LC. The efficacy of acupressure for decreasing agitated behaviour in dementia: a pilot study. Journal of Clinical Nursing 2007;16(2):308-15.

51. McCallion P, Toseland RW, Freeman K. An evaluation of a family visit education program. Journal of the American Geriatrics Society 1999;47(2):20314.

52. Deudon A, Maubourguet N, Gervais X, Leone E, Brocker P, Carcaillon L, et al. Non-pharmacological management of behavioural symptoms in nursing homes. International Journal of Geriatric Psychiatry 2009;24(12):1386-95.

53. Principles for the development of NICE guidance: Social Value Judgements. 2008; National Institute for Health and Care Excellence, London.

54. Romeo R, Zala D, Knapp M, Orrell M, Fossey J, Ballard CJA, et al. Improving the quality of life of care home residents with dementia: Cost-effectiveness of an optimized intervention for residents with clinically significant agitation in dementia. Alzheimer's \& Dementia 2018;15:282-91.

55. Appelhof B, Bakker C, de Vugt ME, Zwijsen SA, Smalbrugge M, Teerenstra S, et al. Effects of a multidisciplinary intervention on the presence of neuropsychiatric symptoms and psychotropic drug use in nursing home residents withyoung-onset dementia: Behavior and Evolution of Young-Onset Dementia Part 2 (BEYOND-II) Study. The American Journal of Geriatric Psychiatry 2019;27(6):581-9.

56. van Duinen-van den IJssel JCL, Bakker C, Smalbrugge M, Zwijsen SA, Adang $\mathrm{E}$, Appelhof $\mathrm{B}$, et al. Cost-consequence analysis of an intervention for the management of neuropsychiatric symptoms in young-onset dementia: Results from the BEYOND-II study. International Journal of Geriatric Psychiatry 2020;35(1):131-137. 
Invited Commentary for International Psychogeriatrics: Time to invest in better dementia care

575. Knapp M, lemmi V, Romeo R. Dementia care costs and outcomes: a systematic review. International Journal of Geriatric Psychiatry 2013;28(6):551-61. 
Invited Commentary for International Psychogeriatrics: Time to invest in better dementia care

Table 1: Studies that have costed individual BPSD in different parts or the world.

\begin{tabular}{|c|c|c|c|}
\hline $\begin{array}{l}\text { Authors, year, } \\
\text { country }\end{array}$ & $\begin{array}{l}\text { Setting, study type, } \\
\text { number of participants } \\
\text { (N) }\end{array}$ & $\begin{array}{l}\text { BPSD, } \\
\text { measure }\end{array}$ & $\begin{array}{l}\text { BPSD cost }(\$ \text { per } \\
\text { unit or predictor } \%)\end{array}$ \\
\hline $\begin{array}{l}\text { Herrmann et al., } \\
\text { 2006, USA } 21\end{array}$ & $\begin{array}{l}\text { Community setting. } 1- \\
\text { year prospective study, } \\
N=500\end{array}$ & Agitation, NPI & $\begin{array}{l}\text { 1-point change } \\
\text { associated with } \\
2 \cdot 3 \% \text { increase in } \\
\text { total costs. (1-point } \\
\text { increase }=\$ 30 \text { per } \\
\text { month }(95 \% \mathrm{Cl} \text { : } \\
\$ 19-\$ 41)\end{array}$ \\
\hline $\begin{array}{l}\text { Jönsson et al., } \\
\text { 2006, Sweden, } \\
\text { Finland and } \\
\text { Denmark }^{39}\end{array}$ & $\begin{array}{l}\text { Community setting. } \\
\mathrm{N}=272 \\
\text { (Costs analysis, } \mathrm{N}= \\
208)\end{array}$ & Agitation, NPI & $\begin{array}{l}\text { 1-point change } \\
\text { associated with } 8 \% \\
\text { increase in total } \\
\text { costs }\end{array}$ \\
\hline $\begin{array}{l}\text { Gustavsson et al., } \\
2011, \text { Sweden }{ }^{14}\end{array}$ & $\begin{array}{l}\text { Community and } \\
\text { residential setting. } \\
\mathrm{N}=1,222\end{array}$ & Agitation, NPI & $\begin{array}{l}1-S D \text { increase } \\
\text { translated to } 8 \% \\
\text { increase in costs } \\
\text { (community setting) }\end{array}$ \\
\hline $\begin{array}{l}\text { Lacey et al., 2013, } \\
\text { ADNI study, Ireland } \\
\& \text { USA } 40\end{array}$ & $\begin{array}{l}\text { Community setting. } \\
\text { Longitudinal observation } \\
\text { study, } \\
\mathrm{N}=138\end{array}$ & Agitation, NPI & $\begin{array}{l}\text { 1-point change } \\
\text { associated with } \\
1.62 \% \text { increase in } \\
\text { total costs }\end{array}$ \\
\hline $\begin{array}{l}\text { Rattinger et al., } \\
2015, \text { USA }^{41}\end{array}$ & $\begin{array}{l}\text { Community setting. } \\
\text { Longitudinal prospective } \\
\text { study, } \mathrm{N}=287\end{array}$ & Agitation, NPI & $\begin{array}{l}\text { 1-point change } \\
\text { associated with } 2 \% \\
\text { increase in informal } \\
\text { costs }\end{array}$ \\
\hline $\begin{array}{l}\text { Wübker et al., 2015, } \\
\text { Spain, Germany \& } \\
\text { France }^{38}\end{array}$ & $\begin{array}{l}\text { Community and } \\
\text { residential setting } \\
\text { (community group 'at } \\
\text { risk'). Prospective } \\
\text { cohort study, } \mathrm{N}=2,014 \\
\text { (Community, } \mathrm{N}=1,048 \text { ) }\end{array}$ & $\begin{array}{l}\text { Agitation, } \\
\text { apathy \& } \\
\text { hallucinations, } \\
\text { NPI }\end{array}$ & $\begin{array}{l}\text { 1-SD increase } \\
\text { translated to } 8 \cdot 8 \% \\
\text { increase in costs } \\
\text { (community setting) }\end{array}$ \\
\hline $\begin{array}{l}\text { Costa et al., } 2018,8 \\
\text { European countries }{ }^{15}\end{array}$ & $\begin{array}{l}\text { Community (homecare) } \\
\text { and residential care } \\
\text { (institutional long-term } \\
\text { care) setting. Cross- } \\
\text { sectional study, } \\
\mathrm{N}=1,997 \text { (Community, } \\
\mathrm{N}=1,217 \text { ) }\end{array}$ & Agitation, NPI & $\begin{array}{l}17 \% \text { increase in } \\
\text { informal care costs } \\
\text { (community setting) }\end{array}$ \\
\hline
\end{tabular}

Abbreviations: NPI, neuropsychiatric inventory; SD, standard deviation. 
Invited Commentary for International Psychogeriatrics: Time to invest in better dementia care

Table 2: Intervention studies that have costed individual BPSD.

\begin{tabular}{|c|c|c|c|}
\hline $\begin{array}{l}\text { Authors, } \\
\text { year, } \\
\text { country }\end{array}$ & $\begin{array}{l}\text { Setting, study type, number } \\
\text { of participants }(N)\end{array}$ & $\begin{array}{l}\text { BPSD, } \\
\text { measure }\end{array}$ & BPSD cost analysis \\
\hline $\begin{array}{l}\text { Mintzer et } \\
\text { al., } 1997 \text {, } \\
\text { USA }{ }^{42}\end{array}$ & $\begin{array}{l}\text { Residential setting, } 2 \\
\text { conditions: } 21-\text { day Inpatient } \\
\text { Programme (IP) \& } \\
\text { Continuum of Care (CC) } \\
\text { (21- vs. } 7 \text {-days } \\
\text { hospitalisation). } \mathrm{N}=178 \\
\text { ( } \mathrm{N}=68 \text { \& } 110 \text { respectively) }\end{array}$ & $\begin{array}{l}\text { Agitation, } \\
\text { CMAI }\end{array}$ & $\begin{array}{l}\text { Change in CMAI score } \\
\text { per US } \$ 1,000: \text { CC: } 0 \cdot 89 \text {, } \\
\text { IP: } 0 \cdot 27 \text { (CC was more } \\
\text { than three times more } \\
\text { cost-effective) }\end{array}$ \\
\hline $\begin{array}{l}\text { Chenoweth } \\
\text { et al., 2009, } \\
\text { Australia }{ }^{25}\end{array}$ & $\begin{array}{l}\text { Residential setting, } 3 \\
\text { conditions: Person-Centred } \\
\text { Care (PCC), Dementia Care } \\
\text { Mapping (DCM) and usual } \\
\text { care. Cluster } \mathrm{RCT}, \mathrm{N}=289 \\
\text { ( } \mathrm{N}=95,77 \text { and } 64 \\
\text { respectively) }\end{array}$ & $\begin{array}{l}\text { Agitation, } \\
\text { CMAI }\end{array}$ & $\begin{array}{l}\text { Incremental cost per } 1- \\
\text { point decrease on CMAI } \\
\text { scale. PCC: AU \$8 AU, } \\
\$ 6 \text { at follow-up. DCC: AU } \\
\$ 49, A \cup \$ 47 \text { at follow-up }\end{array}$ \\
\hline $\begin{array}{l}\text { D'Amico et } \\
\text { al., 2016, } \\
\text { United } \\
\text { Kingdom } 45\end{array}$ & $\begin{array}{l}\text { Community setting, } 2 \\
\text { conditions: exercise and } \\
\text { treatment as usual. } R C T \text {, } \\
\mathrm{N}=52(\mathrm{~N}=30 \text { and } 22 \\
\text { respectively) }\end{array}$ & $\begin{array}{l}\text { Agitation, } \\
\text { NPI }\end{array}$ & $\begin{array}{l}\text { Intervention cost: } £ 284 \\
\text { (range: } £ 190-£ 320 \text { ). } \\
\text { CEAC: willingness to pay } \\
£ 500 \text { per increment } \\
\text { improvement, cost } \\
\text { effective with a probability } \\
\text { greater than } 80 \%\end{array}$ \\
\hline $\begin{array}{l}\text { Mervin et } \\
\text { al., 2018, } \\
\text { Australia }^{32}\end{array}$ & $\begin{array}{l}\text { Residential setting, } 3 \\
\text { conditions: Therapeutic } \\
\text { robotic seal (PARO), soft } \\
\text { seal, usual care. Cluster } \\
\text { RCT, } N=415 \text { ( } N=138,140 \\
\text { and } 137 \text { respectively) }\end{array}$ & $\begin{array}{l}\text { Agitation, } \\
\text { CMAI }\end{array}$ & $\begin{array}{l}\text { AU } \$ 13 \text { incremental cost } \\
\text { per } 1-\text { point decrease on } \\
\text { CMAI scale }\end{array}$ \\
\hline
\end{tabular}

Abbreviations: CEAC, cost-effectiveness acceptability curve; CMAI, Cohen Mansfield agitation inventory; NPI, neuropsychiatric inventory. 